九州大学学術情報リポジトリ

Kyushu University Institutional Repository

\title{
Studies on Life Cycle Assessment of Sugi Lumber
}

Kinjo, Mai

Graduate School of Bioresource and Bioenvironment Sciences, Kyushu Unviersity

Ohuchi, Takeshi

Faculty of Agriculture, Kyushu University

Ki i, Hideyuki

Oita Prefectural Agriculture, Forestry and Fisheries Research Center, Forestry Research Institute

Murase, Yasuhide

Faculty of Agriculture, Kyushu University

https://doi.org/10.5109/4647

出版情報：九州大学大学院農学研究院紀要. 50 (2)，pp.343-351，2005-10-01. Faculty of Agriculture, Kyushu University

バージョン :

権利関係 : 


\title{
Studies on Life Cycle Assessment of Sugi Lumber
}

\section{Mai KINJO', Takeshi OHUCHI*, Hideyuki KII² and Yasuhide MURASE}

\author{
Laboratory of Wood Material Technology, Division of Biomaterial Science \\ Department of Forest and Forest Products Sciences, Faculty of agriculture, \\ Kyushu University, Fukuoka 812-8581, Japan \\ (Received June 30, 2005 and accepted July 26, 2005)
}

\begin{abstract}
Life Cycle Assessment (LCA) is an environmental assessment method that has come into wide use. The LCA method has been used to assess the environmental impact of various products from domestic articles like plastic trays to large buildings. However, few LCA studies on domestic lumber have been conducted because of regional and other differences in forestry methods, distribution, etc. In this study, to obtain basic knowledge on the environmental impact of sugi lumber products, we investigated energy consumption, amount of waste, and volume of product in processes from felling to sawmilling. From the obtained data, emissions of environmental load substances were quantified and evaluated by LCA. The main results obtained are as follow:

$\mathrm{CO}_{2}, \mathrm{CO}, \mathrm{NOx}$, and $\mathrm{SO}_{2}$ were emitted in large quantities from the sawmill subprocess. This is probably due to the large electricity consumption of sawmill equipment. The amount of $\mathrm{CO}_{2}$ emissions depends on the yield of the sawmill and the distance from market of the sawmill. Therefore, effective means to reduce the $\mathrm{CO}_{2}$ emissions were suggested as follow: the sawmill equipment can be rationalized to improve the yield in sawmill subprocess, and the sawmilling line can be made more highly effective; in addition, it is important to plan construction of sawmills so that the distance from the sawmill to the market will be shortest. Global warming and acidification comprise almost the entire result of the impact assessment of both sawmills. The substances that contributed to global warming and acidification were $\mathrm{CO}_{2}, \mathrm{NOx}, \mathrm{SO}_{2}$, and $\mathrm{CH}_{4}$, and each substance was emitted most in the sawmill subprocess. Overall, this study showed that the sawmill subprocess has the greatest role in the environmental load of lumber products.
\end{abstract}

\section{INTRODUCTION}

The Kyoto Protocol has come into effect in February 2005, and related concerns about the environment have increased. Each country has a national reduction target value for emissions of greenhouse gases include carbon dioxide $\left(\mathrm{CO}_{2}\right)$. Japan has to reduce its emissions by $6 \%$, of which $3.9 \%$ is allowed to be reduced from the atmosphere by forests; therefore, appropriate forest management and the promotion of domestic lumber products can be predicted. However, in the production of lumber products, a lot of resources and energy are consumed; the generation of both wastes and environmental load substances cannot be avoided. Therefore, a quantitative analysis of the environmental impact of the production of lumber products is needed.

1 Laboratory of Wood Material Technology, Division of Biomaterial Science, Department of Forest and Forest Products Sciences, Graduate School of Bioresource and Bioenvironment Sciences, Kyushu University

2 Oita Prefectural Agriculture, Forestry and Fisheries Research Center, Forestry Research Institute

* Corresponding author (E-mail: tohuchi@agr.kyushu-u.ac.jp) 
Life Cycle Assessment (LCA) is an assessment method that has recently come into wide use. Full-scale LCA studies were launched in Japan in the 1990s. The LCA method has been used to assess the environmental impact of various products from domestic articles like plastic tray (Kurayoshi and Terashima, 1992) to large buildings. As for lumber products, there have been some studies on LCA abroad, e.g., Energy Audit of Wood Harvesting System (Klavac et al, 2003) or Life Cycle Assessment of Flooring Materials (Jönsson et al, 1997). However, there have been very few studies on domestic lumber production because of regional and other differences in forestry methods, distribution, etc., which make it difficult to obtain all data of the processes involved, from felling to sawmilling.

In this study, to obtain the basic knowledge on the environmental impact of lumber products, we surveyed energy consumption, amount of wastes and volume of product in processes from felling to sawmilling. From the obtained data, emissions of environmental load substances were quantified and evaluated using LCA.

\section{OUTLINE OF INVESTIGATION}

\section{Object of investigation}

Sugi (Cryptomeria Japonica D.Don) lumber (timber, board, and scantling) was chosen as the object of this investigation. Hita city and Hita district (Oita prefecture) comprise a prominent area for forestry in Japan. Many sawmills are located there, and many sugi logs are sold. The half of the investigation covering felling to market was conducted under the auspices of the Hita forestry guild in Hita city; the rest of the investigation was conducted in two sawmills (sawmill I and sawmill II) in Hita district. In sawmill I, the sawing pattern and transportation of lumber between machines was determined by the operator. On the other hand, in sawmill II, the sawing pattern was controlled by computer, and all the processes until drying were composed of one line. Other differences between sawmill I and II are shown in Table 1.

Table 1. Details of sawmills.

\begin{tabular}{lcc}
\hline & Sawmill 1 & Sawmill 2 \\
\hline Volume of products(m ${ }^{3 / \text { day) }}$ & 16 & 100 \\
Number of machines & 12 & 18 \\
Yields at sawmilling process(\%) & 40 & 60 \\
Distances from market to sawmills $(\mathrm{km})$ & 35 & 1 \\
\hline
\end{tabular}

\section{Method of investigation}

Scoping

The scoping of this investigation covered felling to sawmill production. The distribution channel by which logs are felled and transported to the market was first analyzed. The distribution channel is divided into five processes: felling, transportation I, market, transportation II, and sawmill, as shown Figure 1. In the market, logs are classified by 


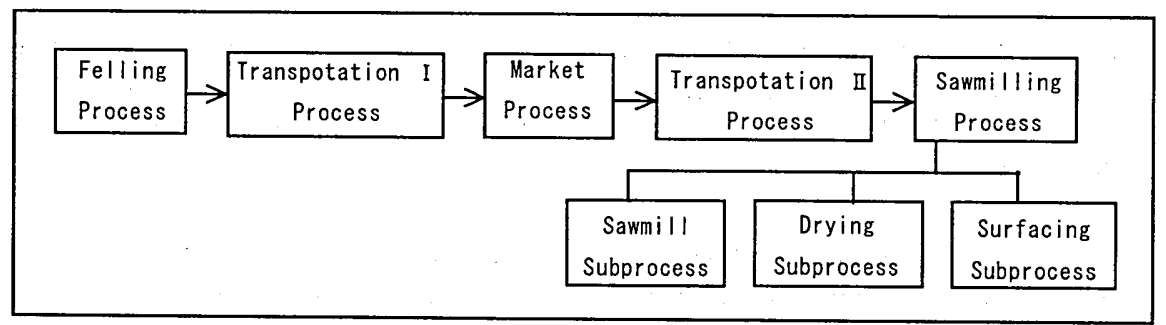

Fig. 1. Flow chart of the distribution channel.

diameter and from there are transported to sawmills. The sawmill process is subdivided into three subprocesses: sawmill, drying, and surfacing.

Inventory data

The following data were investigated in accordance with the processes shown in Table 2. In this study, dust means soot dust which generated in burning diesel oil.

Table 2. Inventory data.

\begin{tabular}{|c|c|}
\hline Processes & Inventory data \\
\hline Felling & $\begin{array}{l}\text { Average age of the logs, Clear-cut or thinning, Type of machine, Working } \\
\text { hours, Type of fuel, Fuel consumption }\end{array}$ \\
\hline Transportation & Type of transportation, Type of fuel, Fuel consumption, Mileage. \\
\hline Market & $\begin{array}{l}\text { Type of machine, Working hours, Volume of product, Type of fuel, Fuel } \\
\text { consumption, Electricity consumption. }\end{array}$ \\
\hline Sawmill & $\begin{array}{l}\text { Type of machine, Working hours, Volume of product, Type of fuel, Fuel } \\
\text { consumption, Electricity consumption, Yield of sawmilling, Yield of } \\
\text { drying, Yield of surfacing. }\end{array}$ \\
\hline
\end{tabular}

\section{Description of the model}

\section{- Felling}

Logs consist of $60 \%$ clear-cut (50 year-old sugi) and $40 \%$ thinning (30 year-old sugi). Clear-cut trees are felled $375 \mathrm{~m}^{3} / \mathrm{ha}$. Thinned trees are felled $40 \mathrm{~m}^{3} / \mathrm{ha}$, and a road $220 \mathrm{~m}$ in length is created. Lubricating oils for machines (Chain saw, Processor and Scraper) are not evaluated and other articles of consumption of machines except for fuel are omitted.

\section{- Transportation I}

Logs are transported $30 \mathrm{~km}$ from the felling place to the market by a $10 \mathrm{t}$ truck. The load capacity of a $10 \mathrm{t}$ truck is set at $10 \mathrm{~m}^{3}$. The mileage of the truck is $3 \mathrm{~km} /$ liter.

- Market

Two types of machine (Forklift and Grapple) are used for carrying logs. The log sorter classifies $225 \mathrm{~m}^{3}$ of logs per day. It is assumed for the calculations that there is no recycling of wastes. However, the transportation of wastes is calculated and included in the market process. 


\section{- Transportation II}

Distances from the market to sawmill I and II are $35 \mathrm{~km}$ and $1 \mathrm{~km}$, respectively. A $10 \mathrm{t}$ truck is used to transport to sawmill $\mathrm{I}$, while a $10 \mathrm{t}$ truck and trailer are used to transport to sawmill II. The load capacities of the $10 \mathrm{t}$ truck and trailer $10 \mathrm{~m}^{3}$ and $30 \mathrm{~m}^{3}$, respectively. Both mileages are set at $3 \mathrm{~km} /$ liter.

- Sawmill

A forklift is used for carrying logs into the sawmills. The volume of products is $10 \mathrm{~m}^{3}$ per day in sawmill I. The energy source of drying is kerosene in sawmill I. In sawmill II, the volume of products is $70 \mathrm{~m}^{3}$. The energy source of drying is heavy oil. Wood chips generated from the sawmill are often used as an alternative energy source for drying. However, wood chips are not included in the inventory because of lack of data. Both sawmills use electricity for sawmilling and surfacing. Yield of surfacing is set to $100 \%$ in both sawmills.

\section{Analysis}

The functional unit used in this study was cubic meters $\left(\mathrm{m}^{3}\right)$.

The database software named JEMAI-LCA ver.1.0 developed by Japan Environmental Management Association was used for analysis. Table 3 shows impact categories and environmental load substances.

Table 3. List of impact categories and environmental load substances.

\begin{tabular}{lc}
\hline Impact categories & Environmental load substances \\
\hline Global warming & $\mathrm{CO}_{2}, \mathrm{~N}_{2} \mathrm{O}$ \\
Acidification & $\mathrm{NO}_{\mathrm{x}}, \mathrm{SO}_{2}$ \\
Eutrophication & $\mathrm{NO}_{\mathrm{x}}$ \\
Winter smog & $\mathrm{CxHy}$ \\
Summer smog & dust, $\mathrm{SO}_{2}$ \\
Toxins for human body & dust \\
\hline
\end{tabular}

\section{Inventory analysis}

In the inventory analysis, energy consumptions, resource consumptions and emissions of each environmental load substances of each process in the life cycle were calculated.

Impact assessment

The inventory results were classified, characterized and evaluated using two impact assessment methods as follow,

- Ecoindicator 95 method

This method was developed in Europe. The data is based on research in Europe.

- National Institute for Resource and Environment Dt method (Dt method)

This method was developed in Japan. The data is based on research in Japan. However, due to lack of data about emissions to water, fewer impact categories could be evaluated with this method.

Table 4 and Table 5 show characterization factors, standard values and weighting factors used in the two assessments. 
Table 4. Characterization factors, standard values and weighting factors (Ecoindicator 95 method).

\begin{tabular}{lccccc}
\hline & $\begin{array}{c}\text { Global } \\
\text { warming }\end{array}$ & Acidification & Eutrophication & $\begin{array}{c}\text { Winter } \\
\text { smog }\end{array}$ & $\begin{array}{c}\text { Summer } \\
\text { smog }\end{array}$ \\
\hline $\mathrm{CO}_{2}$ & 1 & & & & 0.398 \\
$\mathrm{CxHy}$ & & & & 1 & \\
dust & 270 & & & & \\
$\mathrm{~N}_{2} \mathrm{O}$ & & 0.7 & 0.13 & & \\
$\mathrm{NOx}$ & 1 & & & \\
$\mathrm{SO}_{2}$ & & & & & \\
\hline Standard values & $6.50 \mathrm{E}+12$ & $5.60 \mathrm{E}+10$ & $1.90 \mathrm{E}+10$ & $4.70 \mathrm{E}+10$ & $8.90 \mathrm{E}+09$ \\
Weighting factors & 2.5 & 10 & 5 & 5 & 2.5 \\
\hline
\end{tabular}

Table 5. Characterization factors, standard values and weighting factors (Dt method).

\begin{tabular}{lccc}
\hline & Global warming & Acidification & Toxins for humans \\
\hline $\mathrm{CO}_{2}$ & 1 & & 1 \\
dust & & & \\
$\mathrm{N}_{2} \mathrm{O}$ & 310 & 0.7 & \\
$\mathrm{NOx}$ & & 1 & \\
$\mathrm{SO}_{2}$ & & $2.21 \mathrm{E}+09$ & $2.21 \mathrm{E}+09$ \\
\hline Standard values & $1.36 \mathrm{E}+12$ & 1 & 0.127 \\
Weighting factors & 1.14 & & \\
\hline
\end{tabular}

\section{RESULTS AND DISCUSSION}

The results of inventory analysis are shown in Table 6 and Table 7. Four substances $\left(\mathrm{CO}_{2}, \mathrm{CO}, \mathrm{NOx}\right.$ and $\left.\mathrm{SO}_{2}\right)$ are emitted in large quantities in the sawmill subprocess of both sawmills. This is probably due to the large electricity consumption of sawmill equipment. In addition to the above-mentioned substances, dust was also emitted most in sawmill subprocess in sawmill II. This is probably due to the fuel consumption of forklifts in sawmill I. The other substances are emitted most in the transportation II process. Different tendencies were shown in sawmill II. The influence of kerosene consumption in transportation was more remarkable because sawmill I is located further away from the market.

In terms of the total emissions of each substance for each process, $\mathrm{CO}_{2}$ showed the highest value of all substances, regardless of which sawmill. Next were $\mathrm{NO}_{\mathrm{x}}$ and $\mathrm{SO}_{2}$. The $\mathrm{CO}_{2}$ emission of sawmill I and II were ca $260 \mathrm{~kg}$ and ca $105 \mathrm{~kg}$, respectively. According to data of the Hiroshima prefecture forestry guild federation, $1 \mathrm{~m}^{3}$ of sugi lumber can fix ca $200 \mathrm{~kg}$ of $\mathrm{CO}_{2}$. Thus, $75 \%$ of $\mathrm{CO}_{2}$ emissions in sawmill I and $100 \%$ of $\mathrm{CO}_{2}$ emissions in sawmill II are canceled out by the $\mathrm{CO}_{2}$ that the lumber itself fixes. Wood is known as the sole renewable material that can fix $\mathrm{CO}_{2}$. However, these results suggest that much depends on the process of conversion to product form. 
Table 6. Results of inventory analysis (Sawmill I).

\begin{tabular}{|c|c|c|c|c|c|c|c|c|}
\hline \multirow{2}{*}{$\begin{array}{l}\text { Environmental } \\
\text { load } \\
\text { substances }(\mathrm{kg})\end{array}$} & \multirow[t]{2}{*}{ Felling } & \multirow{2}{*}{$\begin{array}{c}\text { Transportation } \\
\text { I }\end{array}$} & \multirow[t]{2}{*}{ Market } & \multirow{2}{*}{$\begin{array}{c}\text { Transportation } \\
\text { II }\end{array}$} & \multicolumn{3}{|c|}{ Sawmilling } & \multirow[t]{2}{*}{ Total } \\
\hline & & & & & Sawmill & Drying & Surfacing & \\
\hline $\mathrm{CO}_{2}$ & 7.346 & 23.774 & 1.771 & 4.128 & 55.764 & 10.943 & 1.198 & 104.923 \\
\hline $\mathrm{CO}$ & 0.001 & 0.005 & 0.000 & 0.001 & 0.007 & 0.001 & 0.000 & 0.015 \\
\hline $\mathrm{C}_{\mathrm{X}} \mathrm{H}_{\mathrm{Y}}$ & 0.001 & 0.003 & 0.000 & 0.001 & 0.001 & 0.001 & 0.000 & 0.006 \\
\hline dust & 0.001 & 0.000 & 0.000 & 0.000 & 0.003 & 0.003 & 0.000 & 0.008 \\
\hline $\mathrm{N}_{2} \mathrm{O}$ & 0.002 & 0.005 & 0.000 & 0.001 & 0.001 & 0.002 & 0.000 & 0.011 \\
\hline $\mathrm{NO}_{x}$ & 0.013 & 0.025 & 0.002 & 0.004 & 0.040 & 0.024 & 0.001 & 0.109 \\
\hline $\mathrm{SO}_{2}$ & 0.004 & 0.012 & 0.001 & 0.002 & 0.041 & 0.006 & 0.001 & 0.067 \\
\hline
\end{tabular}

Table 7. Results of inventory analysis (Sawmill II ).

\begin{tabular}{|c|c|c|c|c|c|c|c|c|}
\hline \multirow{2}{*}{$\begin{array}{l}\begin{array}{l}\text { Environmental } \\
\text { load }\end{array} \\
\text { substances }(\mathrm{kg})\end{array}$} & \multirow[t]{2}{*}{ Felling } & \multirow{2}{*}{$\begin{array}{c}\text { Transportation } \\
\text { I }\end{array}$} & \multirow[t]{2}{*}{ Market } & \multirow{2}{*}{$\begin{array}{c}\text { Transportation } \\
\text { II }\end{array}$} & \multicolumn{3}{|c|}{ Sawmilling } & \multirow[t]{2}{*}{ Total } \\
\hline & & & & & Sawmill & Drying & Surfacing & \\
\hline $\mathrm{CO}_{2}$ & 7.346 & 23.774 & 1.771 & 86.678 & 116.617 & 12.971 & 9.988 & 259.144 \\
\hline $\mathrm{CO}$ & 0.001 & 0.005 & 0.000 & 0.017 & 0.020 & 0.001 & 0.001 & 0.045 \\
\hline $\mathrm{C}_{\mathrm{X}} \mathrm{H}_{\mathrm{Y}}$ & 0.001 & 0.003 & 0.000 & 0.011 & 0.009 & 0.001 & 0.000 & 0.026 \\
\hline dust & 0.001 & 0.000 & 0.000 & 0.001 & 0.002 & 0.004 & 0.000 & 0.009 \\
\hline $\mathrm{N}_{2} \mathrm{O}$ & 0.002 & 0.005 & 0.000 & 0.018 & 0.014 & 0.003 & 0.000 & 0.041 \\
\hline $\mathrm{NO}_{\mathrm{x}}$ & 0.013 & 0.025 & 0.002 & 0.092 & 0.098 & 0.028 & 0.006 & 0.263 \\
\hline $\mathrm{SO}_{2}$ & 0.004 & 0.012 & 0.001 & 0.042 & 0.071 & 0.007 & 0.008 & 0.144 \\
\hline
\end{tabular}

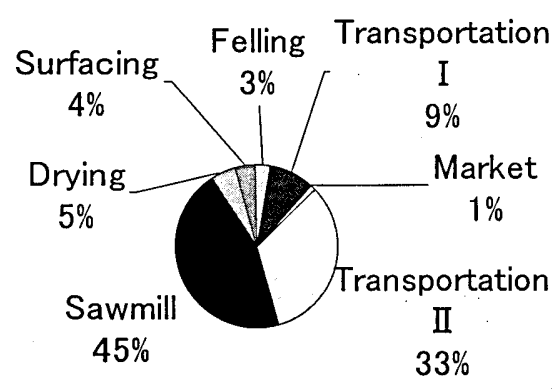

Sawmill I

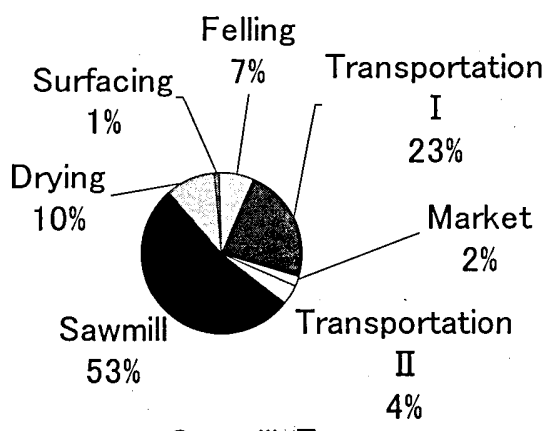

Sawmill II

Fig. 2. Details of $\mathrm{CO}_{2}$ emission. 
Figure 2 shows details of $\mathrm{CO}_{2}$ emissions of each subprocess for sawmill I and II. The sawmill subprocess made up nearly $50 \%$ in both results. Nevertheless, there are differences in actual values between the results of the two sawmills, not only in the sawmill subprocess but also in the other processes, especially transportation. The difference in sawmill subprocesses is probably due to the respective yields of the sawmills, originating in the differences in sawmill equipment and the sawmilling lines. The difference in transportation II is due to the difference in the distance from market of the two sawmills.

From these results, effective means for reducing $\mathrm{CO}_{2}$ emissions are suggested as follow: the sawmill equipment can be rationalized to improve the yield in the sawmill subprocess, and the sawmilling line can be made more highly effective; in addition, it is important to plan construction of sawmills so that the distance from the sawmill to the market will be shortest.

\section{Impact assessment}

\section{Ecoindicator 95 method}

The results of impact assessment in both sawmills by the Ecoindicator 95 method are shown in Figure 3. From this figure, global warming has the largest rate among all impact categories. Acidification, eutrophication, summer smog and winter smog follow, in that

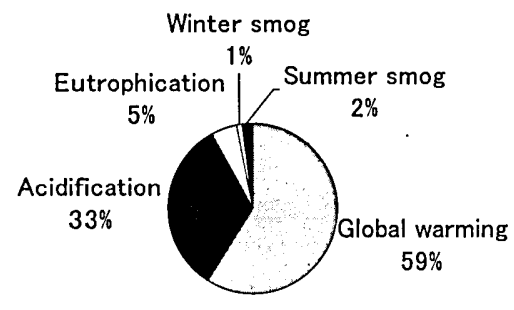

Sawmill I

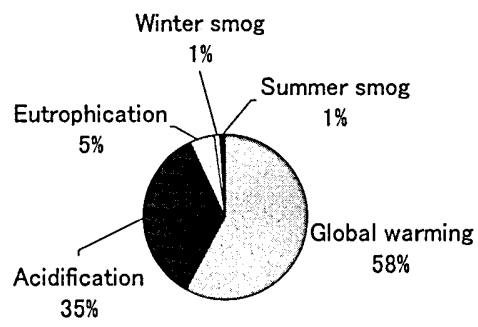

Sawmill II

Fig. 3. Results of impact assessment (Ecoindicator 95 method).

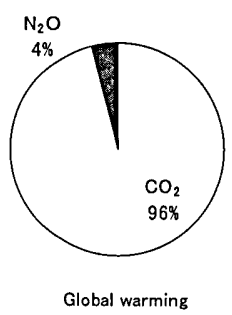

Sawmill 1

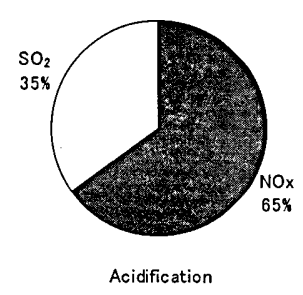

Acidification

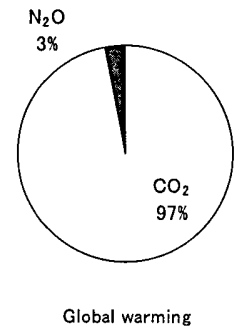

Sawmill 2

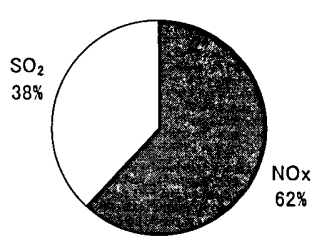

Acidification

Fig. 4. Details of global warming and acidification (Ecoindicator 95 method). 
order.

The details of global warming and acidification in both sawmills are shown in Figure 4 . $\mathrm{CO}_{2}$ made up $96 \%$ of the factors for global warming and NOx made up $63 \%$ of the factors for acidification.

National Institute for Resources and Environment Dt method (Dt method)

The results of impact assessment in both sawmills by the Dt method are shown in Figure 5. As with the Ecoindicator 95 method, global warming was shown to have the largest rate. Acidification and toxins to humans followed.

The details of global warming and acidification are shown in Figure 6 . In the Dt method, $\mathrm{CO}_{2}$ made up $95 \%$ of the factors responsible for global warming, and NOx made up $50 \%$ of the factors responsible for acidification.

From the above-mentioned results of impact assessment using both Ecoindicator 95 and $\mathrm{Dt}$ methods, it became clear that global warming and acidification comprise almost the entire impact. The major substances that contributed to global warming and acidification were $\mathrm{CO}_{2}, \mathrm{NOx}, \mathrm{SO}_{2}$ and $\mathrm{CH}_{4}$. The contribution to global warming by $\mathrm{CO}_{2}$ was especially remarkable. Furthermore, the results of inventory analysis clarified that each substance was emitted most in the sawmill subprocess. Overall, this study showed that

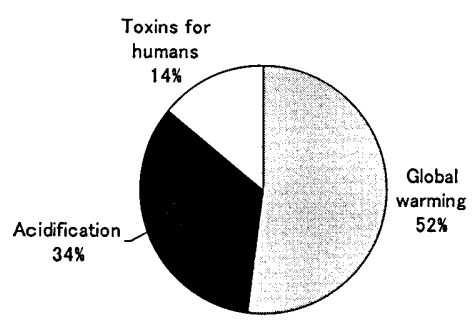

Sawmill I

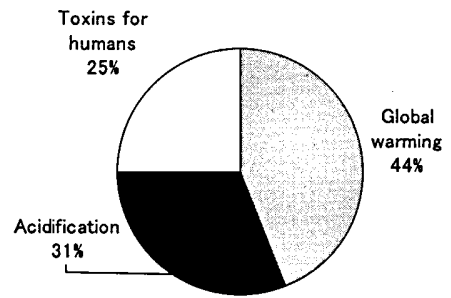

Sawmill II

Fig. 5. Results of impact assessment (Dt method).

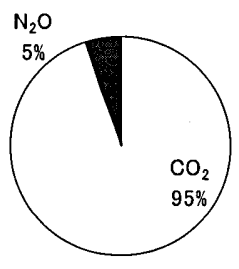

Global warming

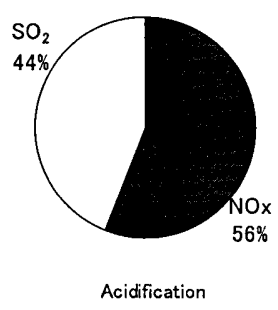

Sawmill I
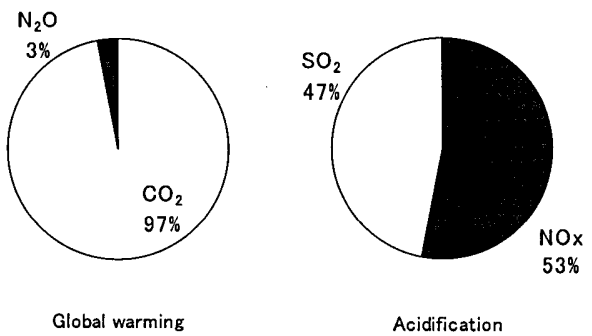

Acidification

Fig. 6. Details of global warming and acidification (Dt method). 
the sawmill subprocess has the greatest role in the environmental load of lumber products.

\section{CONCLUSIONS}

In this study, to obtain basic knowledge of the environmental impact of lumber products, we surveyed energy consumption, amount of wastes, and volume of product in the related processes from felling to sawmilling. From the obtained data, emissions of environmental load substances were quantified and evaluated using LCA. The main results were as follow:

1) $\mathrm{CO}_{2}, \mathrm{CO}, \mathrm{NOx}$, and $\mathrm{SO}_{2}$ were emitted in large quantities from the sawmill subprocess.

This is probably due to the large electricity consumption of sawmill equipment.

2) The amount of $\mathrm{CO}_{2}$ emissions depends on the yield of the sawmill and the distance from market of the sawmill. Therefore, effective means to reduce the $\mathrm{CO}_{2}$ emissions were suggested as follow: the sawmill equipment can be rationalized to improve the yield in sawmill subprocess, and the sawmilling line can be made more highly effective; in addition, it is important to plan construction of sawmills so that the distance from the sawmill to the market will be shortest.

3) Global warming and acidification comprise almost the entire result of the impact assessment of both sawmills. The substances that contributed to global warming and acidification were $\mathrm{CO}_{2}, \mathrm{NOx}, \mathrm{SO}_{2}$, and $\mathrm{CH}_{4}$, and each substance was emitted most in the sawmill subprocess. Overall, this study showed that the sawmill subprocess has the greatest role in the environmental load of lumber products.

\section{REFERENCES}

Architectural Institute of Japan 2003 LCA guidance of buildings, $2^{\text {nd }}$ ed. Architectural Institute of Japan publication, Tokyo

Forestry Agency Plan Section 2002 Forest and Forestry. (Japan) 575: 4-13

Forestry Agency Project Section 2003 Forest and Forestry. (Japan) 589: 4-12

Forestry and Forest Products Research Institute 2004 Wood Industry Handbook, $4^{\text {th }}$ ed. Maruzen publication, Tokyo

Hiroshima prefecture forestry guild association Q\&A about wood In http://www.mokuren. org/mori/index_3.htm

Japan Environmental Management Association For Industry 1999 Introduction to LCA practical business, $2^{\text {nd }}$ ed. Japan Environmental Management For Industry publication, Tokyo

Jönsson, A., A-M. Tillman and T. Svensson 1997 Life Cycle Assessment of Flooring Materials: Case. Building and Environment, 32(3): 245-255

Klvac, R., S. Ward, P. M. O. Owende and J. Lyons 2003 Scandinavian Journal of Forest Research, 18: 176-183

Kurayoshi, I., Y. Terashima 1992 Japan Society of Waste Management Experts $3^{\text {rd }}$ Annual Conference proceedings: $43-46$

The Society of Non-Traditional Technology 1998 All of $L C A, 3^{\text {rd }}$ ed. Kogyo Chosakai publication, Tokyo

Tokyo University of Agriculture and Technology 2005 Forestry Practical Business, $3^{\text {rd }}$ ed. Asakura publication, Tokyo 